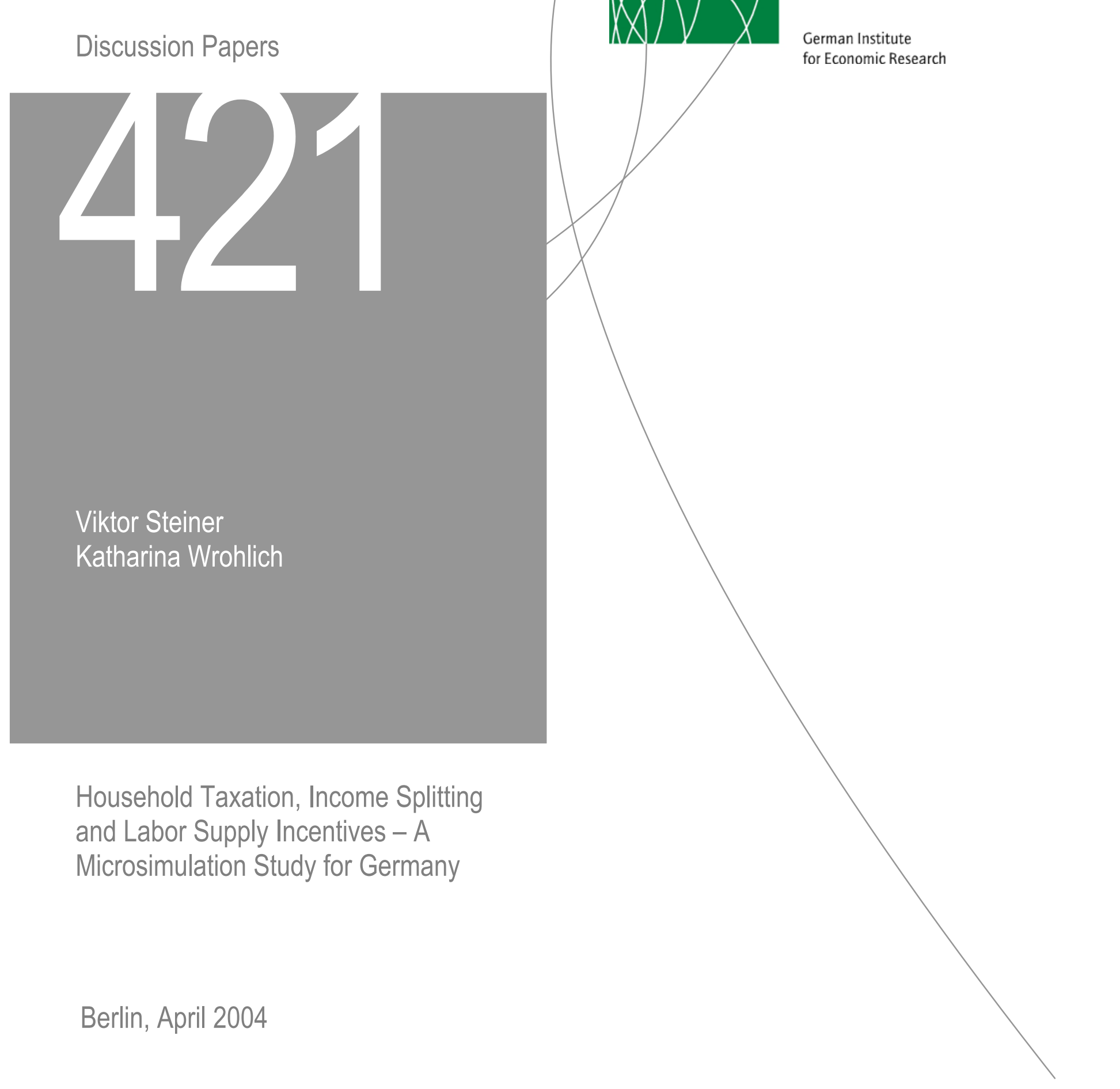


Opinions expressed in this paper are those of the author and do not necessarily reflect views of the Institute.

DIW Berlin

German Institute

for Economic Research

Königin-Luise-Str. 5

14195 Berlin,

Germany

Phone +49-30-897 89-0

Fax $\quad+49-30-89789-200$

www.diw.de

ISSN 1619-4535 


\title{
Household Taxation, Income Splitting and Labor Supply Incentives - A Microsimulation Study for Germany
}

\author{
Viktor Steiner \\ Katharina Wrohlich \\ Free University Berlin \\ German Institute of Economic Research (DIW Berlin) \\ $(13 / 04 / 2004)$
}

\begin{abstract}
:
We analyze potential labor supply effects of a shift from the current German system of joint taxation of married couples to a system of limited real income splitting on the basis of an econometric household labor supply model embedded in a tax-benefit model. Our simulation results show relatively small labor supply effects of a shift from the current system to one of limited real income splitting system. In the benchmark scenario of a shift to separate taxation labor supply of wives would increase substantially in west Germany, while a significant number of husbands would drop out of the labor force.
\end{abstract}

JEL Classification: H31, H24, J22

\section{Correspondence to:}

Viktor Steiner

DIW Berlin

Königin-Luise Str. 5

14195 Berlin

email: vsteiner@diw.de

Acknowledgement: We thank Volker Meier and participants of the cesifo Venice Summer Institute workshop on "Taxation and the Family" for helpful comments on a previous version of this paper. 


\section{$1 \quad$ Introduction}

The joint taxation of married couples in Germany has been a controversial issue in practical fiscal and social policy for some time. There has also been a long-standing debate among economists about the normative rationale as well as allocation and distribution effects of the special taxation of married couples in Germany, known as "income splitting". This principle means that the income tax of a married couple is calculated by applying the tax function to half of the added incomes of the spouses, and this amount is then doubled to determine the tax amount of the couple. Under the German system of progressive taxation this implies that the amount of the income tax of a married couple may be lower than the tax the same couple would have to pay if both spouses were taxed individually according to the principle of separate taxation. The difference in the tax under these two principles depends both on the level of household income and the distribution of incomes between the two spouses. In popular German discussion, this difference is termed the "splitting advantage" of the joint taxation of married couples.

There are two prevalent criticisms of this alleged "splitting advantage": First it is seen as a subsidy to married couples with the traditional division of labor within the household, where the wife as the secondary earner stays at home. In this view, the relatively low labor force participation rate of married women in Germany is closely related to the negative labor supply incentives for second earners implied by the tax system. ${ }^{1}$ From a social policy perspective, critics also point out that income splitting is not an adequate means of family policy as it does not subsidize households with children but married couples, while increasingly these two groups cease to coincide. In contrast, the majority view among public finance experts seems to be that there is no "splitting advantage" at all. Rather, the difference in the amount of taxes paid by married couples is considered to be the logical consequence of the system of progressive taxation, given the widely agreed normative rules that the tax system should not discriminate against marriage and, at the same time, should be neutral with respect to the distribution of incomes within the household (see, e.g., Spahn, Kaiser and Kassella, 1992, Homburg, 2000).

In this paper, our focus is on the positive issue of the negative incentives of the current German system of income splitting on labor supply of wives. In particular, we will simulate

\footnotetext{
For example, comparing the Swedish system of separate taxation of married couples with the German system of income splitting, Gustafsson (1992: 61) states: "The German wife, on the other hand, has to earn enough to offset the marriage gain, before she contributes to family income, and marginal earnings of the second wage earner are hit by a high tax rate".
} 
the labor supply effects of a shift to some other system of taxation. To this end, we analyze two hypothetical reforms: (i) a shift to a system of individual income taxation, and (ii) the proposal of "limited real income splitting". For both political and constitutional reasons, it seems very unlikely that individual taxation for spouses will be introduced in Germany. The second reform proposal, which limits the amount of the "splitting advantage", has been discussed during the last election campaign by the ruling coalition and it is likely that this proposal will show up in the future.

To simulate the labor supply effects of these hypothetical reforms, we develop a microsimulation model which integrates an empirical household labor supply model into a detailed tax-benefit model based on the German Socio Economic Panel (GSOEP). The labor supply model is based on the hypothesis that both spouses jointly maximize a utility function in the arguments leisure of both spouses and net household income. This "household utility" model differs in important ways from previous studies on the labor supply effects of household taxation in Germany. In these studies, the specification of the household labor supply model is based on the "male chauvinist" assumption: that is, the wife is assumed to adjust her labor supply to that of the husband who, in turn, does not care about his wife's labor supply behavior. We believe that the behavioral assumption underlying our econometric labor supply model is a better description of actual behavior than the one implied by the "male chauvinist" labor supply model. In particular, our model allows us to estimate the effects of a change in household taxation on the labor supply of both spouses, whereas previous studies have only looked at the wife's labor supply decision. Furthermore, we also estimate the effects of the change in taxation on both spouses' labor force participation and the hours decision simultaneously.

In the next section, we briefly describe the German system of taxation of married couples and define the so-called "splitting advantage" referred to above. We also briefly summarize the empirical studies on the potential labor supply effects of reforms in household taxation in Germany relevant for our study. In section 3, we present the econometric specification of our labor supply model, which we then use to simulate the shift from the current system of income splitting to the hypothetical benchmark of separate taxation and a more realistic "limited real income splitting" scenario. Simulation results for the implied income effects (for given labor supply) and the effects of this shift on labor supply in Germany are summarized in section 4 . The main results of our study are summarized in the concluding section 5 . 


\section{Distribution and Labor Supply Effects of "Income Splitting"}

To set the scene for our simulation study of the potential labor supply effects of a shift from the current German system of income splitting to other forms of household taxation, in the following section we briefly describe different income tax regimes for married couples and illustrate the "splitting advantage" for the German case. In section 2.2, we briefly summarize previous empirical studies on the effects of income splitting on labor supply of married women in Germany.

\subsection{Household Taxation, Income Splitting, and the "Splitting Advantage"}

Income tax regimes of European countries differ greatly regarding the tax treatment of married couples. In some countries (Sweden, Austria, Great Britain) ${ }^{2}$, individuals are taxed subject to their own income, independently of their marital status. Other countries, such as France, the US, or Germany, treat married couples as a single tax subject and tax the incomes of spouses jointly. To avoid the "marriage penalty" that arises in a progressive tax system as a consequence of joint taxation, Germany allows income splitting between spouses: The income tax of a married couple is calculated by applying the tax function to half of the sum of the spouses' incomes; this amount is then doubled to determine the tax amount of the couple. In Figure 1, the German system of joint taxation with income splitting is compared with the system of separate taxation and a modified system of separate taxation.

Figure 1-Income tax regimes for married couples

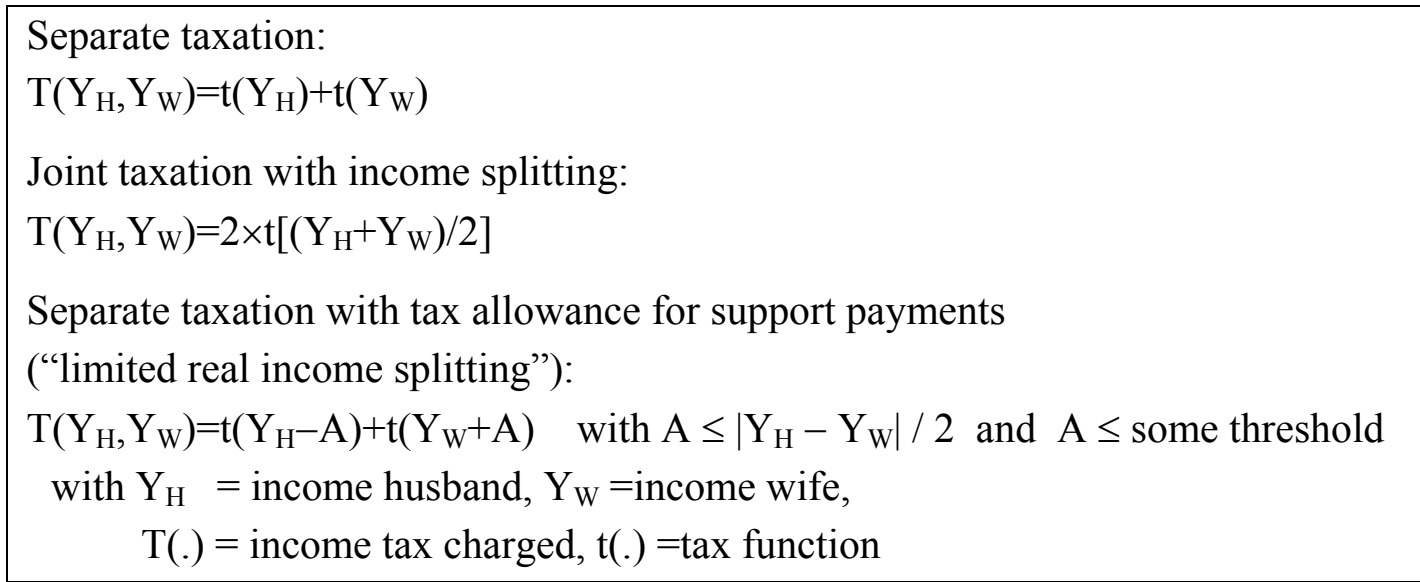

Income splitting guarantees that married couples, given a certain household income, will always be charged the same amount of income tax, no matter how income is distributed

2 For a survey on the income tax systems of European countries, see for example Dingeldey (2001). 
between husband and wife. It therefore also implies that no married couple will pay higher income taxes than a single individual with the same household income. This tax neutrality towards the income distribution between spouses, however, leads to non-neutrality towards marital status. An unmarried couple could "save" taxes through marriage because of the "splitting advantage". ${ }^{3}$ The "splitting advantage" is defined as the difference between the tax amount that a married couple pays under income splitting and the amount the same couple would pay in case of separate taxation. The amount of this advantage depends on the income distribution between husband and wife and on the absolute level of household income. In the following figure the splitting advantage is illustrated for the tax function of the years 2002/ $03^{4}$.

\section{Figure 2-"Splitting Advantage" for married couples under the current system of income taxation in Germany (2002/03)}

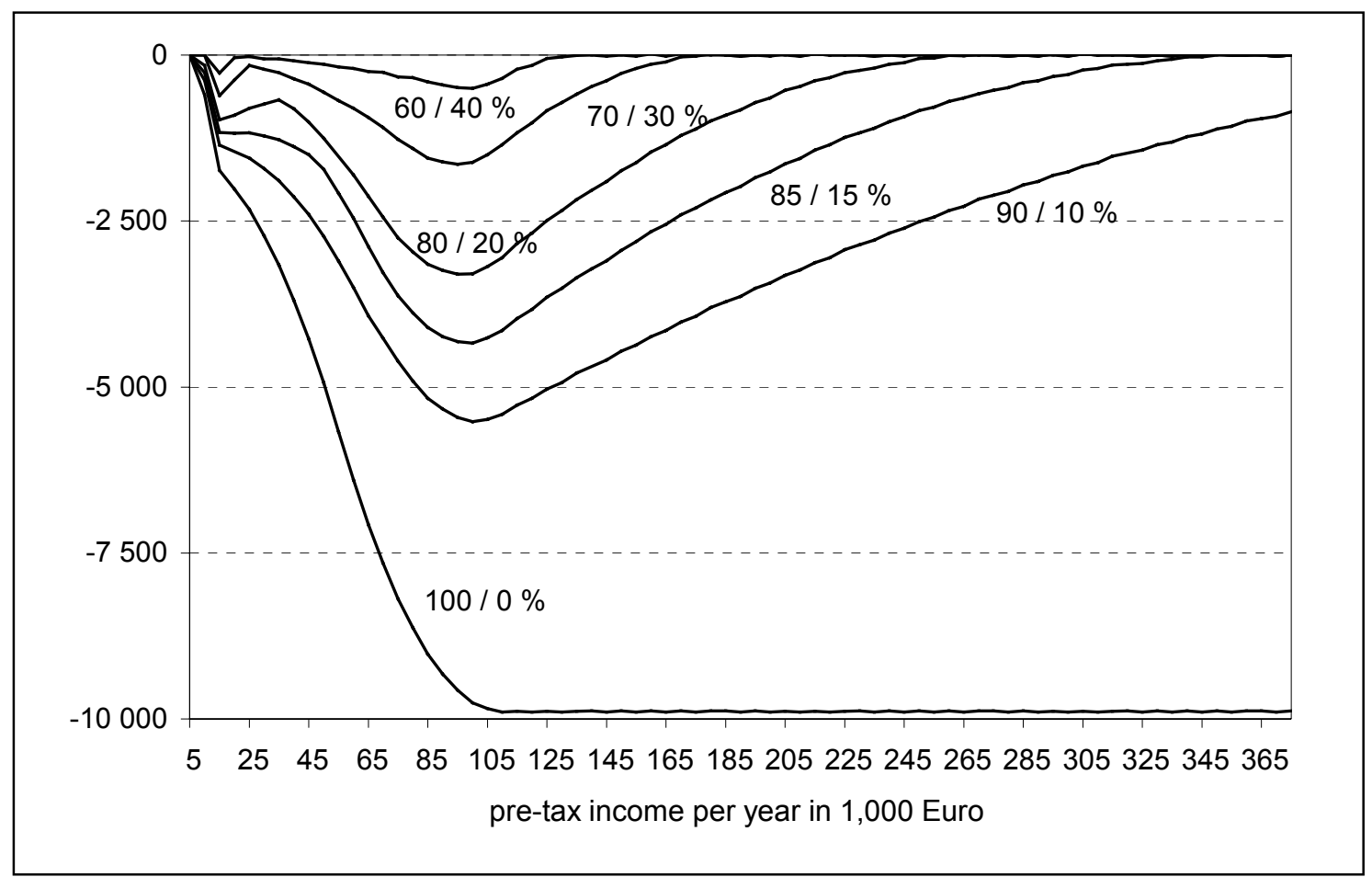

Note: The first (second) number refers to the husband's (wife's) percentage share in the spouses' joint household pre-tax income per year (in $€$ ).

Source: Calculations by the German Institute of Economic Research (DIW Berlin).

3 As mentioned in the introduction, the connotation of the term „splitting advantage“ is open to question. For a discussion of the impossibility of jointly fulfilling all reasonable objectives on a system of taxing couples, see Spahn, Kaiser and Kassella (1992).

4 In contrast to Germany, in the US the joint taxation of married spouses leads to a "marriage penalty" for some couples and a "marriage bonus" for others, depending on household income and on the income distribution within the household (see Dickert-Conlin and Houser 1998). 
As can be seen from Figure 2, the splitting advantage attains its maximum for single earner households. Whith an increasing share of second earner's income, the splitting advantage declines rapidly. In the case of a couple with a pre-tax income of $100,000 €$ per year, according to the tax function of the year 2002/03, the splitting advantage is $9,757 €$ for a single-earner couple. The splitting advantage declines to $5,524 €$ if the income share of the second earner is $10 \%$, given constant household income. For couples with a second-earner income share of $30 \%$, the splitting advantage shrinks to $1,618 €$. On the other hand, for a given share of second earner's income, the splitting advantage clearly increases (in absolute terms) with increasing pre-tax household income. The relative share of the splitting advantage, however, does not follow a monotonic trend. For single-earner households, the splitting advantage is $12 \%$ of after-tax household income for couples with a pre-tax income of $50,000 €$. This share increases to $14 \%$ (pre-tax income of $75,000 €$ ), and declines to $12 \%$ for households with a pre-tax income of $125,000 €$. The upper limit of the splitting advantage is $9,899 €$ according to the tax tariff function of $2002 / 03$. It is attained by single-earner households with a pre-tax income amounting to twice the income limit after that the highest tax rate cuts in.

One of the reform proposals that has repeatedly been suggested, the so-called "limited real income splitting", leaves the "splitting advantage" for married couples with unequal income distribution in place, but reduces its quantitative importance. In this system, married couples are taxed separately, but the spouse with higher income can deduct a tax allowance for support payments; the second earner has to add this tax allowance to his own taxable income (see Figure 1). The tax allowance is limited to $20,000 €$ per year and cannot exceed 50 per cent of the difference between the incomes of the spouses ${ }^{5}$. Under this regime, income differences up to $40,000 €$ can be balanced in the same way as under the current income splitting; only for spouses with income differences above this amount, the "splitting advantage" is cut.

In the following sections, we will analyze two hypothetical reforms of the current system of household taxation in Germany, namely (i) a shift to a system of individual income taxation, and (ii) the proposal of the limited real income splitting. It seems unlikely, due to constitutional arguments, that individual taxation for spouses will be introduced in Germany. The second reform proposal, however, has been discussed during the last election campaign by the ruling coalition and it seems likely that this proposal will show up again in the future.

5 It should be noted that without the limitation of the tax allowance, real income splitting would equal the current income splitting in Germany. For a discussion hereon, see Homburg (2000). 
Before we turn to the simulation of the potential labor supply effects of these proposals, we briefly summarize the empirical studies of similar reforms of the system of joint taxation in Germany.

\subsection{Labor Supply Effects - Previous Empirical Studies for Germany}

There are only a few empirical studies that analyze the effects of a reform of household taxation on labor supply of married women and on the income distribution in Germany (Wagenhals and Kraus 1998, Althammer 2000, Spahn, Kaiser and Kassella 1992, Gustafsson 1992). All of these studies are based on the German Socio-Economic Panel Study (GSOEP) and estimate standard labor supply models for married couples, where the focus is on the labor supply response of wives to a shift from the system of income splitting to separate taxation. All these studies are based on the so-called "male chauvinist" assumption (Killingsworth, 1983). That is, it is assumed that the wife's labor supply depends on her own marginal net wage rate, which is a function of the gross wage rate and the tax function. Policy variations are simulated by a change in the tax function that determines the wife's marginal net wage rate. The husband's labor supply decision is assumed to be exogenously given for the labor supply decision of his wife.

Wagenhals and Kraus (1998) analyze numerous policy variations, amongst others individual taxation, income splitting with splitting divisors of 1.6 and 1.8, some variations of limited real income splitting, and family splitting ${ }^{6}$. For the case of a shift to individual taxation (which is the only policy reform that is comparable to the simulated reform proposals presented in our paper), Wagenhals and Kraus calculate an increase of the female labor force participation rate of 26 percentage points (from 59\% under the status quo to $85 \%$ under separate taxation).

Althammer (2000) also simulates income tax policy variations on the basis of GSOEP data from the year 1996. Policy shifts to family splitting and various sorts of limited real income splitting are analyzed, with all policy variations modelled to be neutral in tax revenues. The wife's labor supply is explained by the marginal net wage rate and other net household income. Therefore, policy shifts are simulated by changes in the marginal wage rate via changing the tax function, assuming that the wife's income is taxed as the secondary income in the high-tax bracket under the current system of joint taxation. In case of a shift to

\footnotetext{
6 In the case of family splitting, the splitting divisor depends on the number of children in the household.
} 
limited real income splitting (with different tax allowances than the proposal studied in our paper), the female participation rate increases by 0.7 percentage points, from $69.5 \%$ to $70.2 \%$.

Labor supply effects of a change to individual taxation and to limited real income splitting are also studied in Spahn, Kaiser and Kassella (1992). As in Althammer (2000), these policy variations are set up to be neutral in tax revenues. Female labor supply is modelled as a linear function of marginal net wage rate and other net household income. In case of a policy shift to a form of limited real income splitting, female labor supply, measured in total hours worked by year, increases by $11.8 \%$. The simulated policy reform, however, is not directly comparable to the one we present below, because it includes higher child allowances to achieve revenue neutrality and higher tax allowances for support payments.

Gustafsson (1992) analyzes the labor supply reaction of German women in the case that the Swedish income tax system (individual taxation) were to be implemented in Germany. Female labor supply is estimated by applying a logit model with two alternatives, namely wife's labor supply of 10 hours per week and wife's labor supply of 40 hours per week. These alternatives are compared to the case that the wife does not work at all. Independent variables in the model are the pre-tax wage rate, net average wage rate, given the hours worked per week, and net household income in case the wife is not working. The result, based on GSOEP data from 1984, is an increase of the female participation rate of almost 10 percentage points (from 50.3 to $60 \%$ ) in case of the introduction of the Swedish income tax system in Germany.

Overall, the majority of these studies finds relatively large labor supply effects of a shift from the current German system of joint taxation with income splitting to some form of separate taxation or limited real income splitting. These effects were derived under the assumption of the "male chauvinist" model. We doubt that this hypothesis adequately describes household labor supply in Germany. Furthermore, the studies reviewed above do not take into account that a change in household taxation may not only affect wives' but also husbands' labor supply, presumably in an opposite direction. In the next section, we therefore develop an econometric model of household labor supply based on less restrictive behavioral assumptions which also allows us to simulate the effects of changes in household taxation on husbands' labor supply behavior.

\section{Econometric Specification}

In this section, we extend previous work by Steiner (2000) and integrate a household labor supply model with a tax-benefit simulation model. Given the complexities of the German tax and income transfer systems and the existence of means-tested social transfers, a detailed 
specification of the household's budget constraint seems crucial when analyzing the incentive effects of houshold taxation, and the joint filing of taxes of couples in particular.

\subsection{The Household Labor Supply Model}

There are various specifications of empirical household labor supply models in the literature (for a recent summary see Blundell und MaCurdy, 1999). The most commonly used specifications are the so-called "male chauvinist" model and the household utility model. As it was already mentioned in section 2 above, in the former model it is assumed that the wife takes the husband's labor supply as given in her own labor supply decision, whereas the husband does not take his wife's labor supply decision into account in deciding on his own labor supply. In contrast, the household utility (HU) model is based on the assumption that both spouses jointly maximize a utility function in the arguments leisure of both spouses and net household income. In our view, the HU model is a more adequate description of actual household behavior in Germany. ${ }^{7}$ For the specification of the male chauvinist model, a net wage rate for each spouse has to be defined. Under the German system of joint taxation, however, this definition is not possible without critical assumptions. The above-cited studies assume that the net wage of the wife is the one which is obtained when applying the high tax bracket for secondary earners. As a consequence, the husband's income, which enters the labor supply decision of the wife as "other income", is relatively high. However, this distribution of taxes between spouses is only an assumption. If equal tax brackets were assumed, the net wage rate of the wife would rise, while the husband's income (which is the wife's "other income") would fall. In the "male chauvinist" specification of labor supply, the effects of a reform of the splitting regime are driven by the change in the net wage rates. The results are therefore very sensitive to the critical assumption on the choice of the tax brackets of the spouses.

To make the household labor supply model tractable, we assume that the labor supply decisions of the household head and the spouse can be separated from the labor supply decisions of all other household members. That is, it will be assumed that other household members' labor supply does not affect the spouses' joint labor supply decision.

7 The more recent „collective“ models of household labor supply do not specify a common utility function of the household but, starting from individual utility function and taking into account strategic interactions between the spouses, derive optimal (pareto-efficient) sharing rules for income and leisure within the household (see, e.g., Blundell and MaCurdy, 1999, section 7.2 for a summary). The empirical identification of this type of model is very demanding and, so far, the application of this approach to the empirical analyses of practical policy problems has been rather limited. 
In contrast to traditional labor supply studies, we model hours supplied by the household as a categorical rather than as a metric variable. This form of modelling takes into account the fact that hours of work are heavily concentrated at particular hours, such as 0,15 , 20 and 40 hours for women, and zero and 40 hours for men. This peculiar hours distribution cannot adequately be approximated by specifying a continuous hours distribution. Second, the specification of hours categories reduces measurement errors in the number of hours actually worked. Thirdly, and most importantly, the specification of a relatively small number of hours categories leads to a big reduction in the computational burden of calculating the potential net household income at each possible hours choice. This simplification, in fact, is a perequisite for an adequate specification of the budget contstraint given the complexities of the German tax-benefit system.

The household's labor supply decision is modelled by a utility function which is assumed to depend on the leisure time of the male $\left(L_{\mathrm{m}}\right)$ and the female $\left(L_{\mathrm{f}}\right)$ spouse as well as on real net household income $(Y)$. Following van Soest (1995), we assume that the household's utility index for a particular hours category, $k$, can be modelled by the following translog function:

$$
U_{k}\left(x_{k}\right)=x_{k}^{\prime} A x_{k}+\beta^{\prime} x_{k}+\varepsilon_{k},
$$

where $x=\left(y, l_{\mathrm{m}}, l_{\mathrm{f}}\right)^{\prime}$. The components of $x$ are the (natural) logs of net household income, leisure of the husband and the wife, respectively. These components enter the utility function (1) with linear, quadratic and cross terms between the spouses' leisure terms and household income. The matrix $A$, with elements $\alpha_{\mathrm{ij}}, i, j=(1,2,3)$, contains the coefficients referring to the non-linear terms, the vector $\beta_{\mathrm{j}}, j=(1,2,3)$, the corresponding coefficients of the linear terms. $\varepsilon$ is a stochastic error term accounting for factors affecting the household's utility other than leisure and income. The distribution of this error term will be specified below.

The advantage of this functional form specification relative to more restrictive specifications of preferences, such as the Cobb-Douglas or CES utility functions, is its flexibility. In particular, equation (1) allows for the dependence of the utility of one spouse's hours of leisure on the other spouse's leisure as well as the utility of each spouse's leisure to depend on the level of net household income.

In the $H U$ model, the utility index should be concave in household income and, for given household income, be increasing in both spouses' leisure time (provided working hours were initially positive). Moreover, the first derivative of the utility index with respect to leisure time should, ceteris paribus, be positive for both spouses, provided leisure is a normal 
good, while the second derivative is expected to be negative. The cross-substitution effect between the two spouses' leisure time is theoretically ambiguous. That is,

$$
\begin{aligned}
& \frac{\partial U(\cdot)}{\partial y}>0 ; \frac{\partial^{2} U(\cdot)}{\partial y^{2}}<0 ; \\
& \frac{\partial U(\cdot)}{\partial l_{f}}>0 ; \frac{\partial U(\cdot)}{\partial l_{m}}>0 ; \\
& \frac{\partial^{2} U(\cdot)}{\partial l_{f}{ }^{2}}<0 ; \frac{\partial^{2} U(\cdot)}{\partial l_{m}{ }^{2}}<0 ; \frac{\partial^{2} U(\cdot)}{\partial l_{f} \partial l_{m}}=? ; \frac{\partial^{2} U(\cdot)}{\partial l_{m} \partial l_{f}}=?
\end{aligned}
$$

These theoretical implications can be tested by calculating respective derivatives of the utility index for each household evaluated at the parameter estimates from the econometric model described below. The sign of the cross effects depend on whether the two spouses' leisure times are substitutes or complements. The latter seems more likely to be the case because leisure spent with the spouse is probably valued higher than an equivalent amount of time spent alone. Of course, this ultimately is an empirical question which can only be resolved on the basis of econometric work.

Given the assumption of joint maximization of household utility, the household will choose hours category $k$ if, in probability terms, the associated utility index, $U_{\mathrm{k}}$ exceeds the utility in any other possible alternative $l$, i.e.:

$$
P\left(U_{k}>U_{l}\right)=P\left(\left(x_{k}{ }^{\prime} A x_{k}+\beta^{\prime} x_{k}\right)-\left(x_{l}{ }^{\prime} A x_{l}+\beta^{\prime} x_{l}\right)>\varepsilon_{l}-\varepsilon_{k}\right)
$$

To obtain an estimable econometric specification of the household labor supply model described in the previous section, we have to specify a distribution of the stochastic component of the utility function, i.e. $\varepsilon_{k}$. Assuming that $\varepsilon_{k}$ is distributed identically across all hours categories according to an extreme-value distribution, the difference of the utility index between any two hours categories follows a logistic distribution. As it is well known (McFadden, 1973), under this distributional assumption the probability of choosing alternative $k$ relative to alternative $l$ can be described by a Conditional Logit Model (CLM), i.e.:

$$
P\left(U_{k}>U_{l}\right)=\frac{\exp \left(x_{k}^{\prime} A x_{k}+\beta^{\prime} x_{k}\right)}{\sum_{m} \exp \left(x_{m}^{\prime} A x_{m}+\beta^{\prime} x_{m}\right)}, \forall l \neq k,
$$


where the summation sign is defined over all possible alternatives, i.e. hours categories. ${ }^{8}$

For given levels of income and leisure for both spouses, household utility also depends on certain household characteristics, such as the age and the health status of both spouses as well as the number and age of children in the household. This dependence is accounted for in the model by specifying the parameters $\beta_{\mathrm{j}}$ as functions of these variables. The specification of these functions may differ by gender, as it seems likely that children in the household have different effects on men's and women's leisure time.

As specified here, the CLM only identifies parameters of variables which vary between alternatives. Variables with no variation across alternatives drop out of the estimation due to the fact that only differences in the utility index between alternatives are compared here. Hence, the estimation of income effects relies on the differences in the level of net household income between the hypothetically chosen hours categories rather than on the income level itself. Characteristics specific to the household or the spouses, like the presence of children, disability or age are identified by the assumption that their effects on household utility depend on the hours category.

\subsection{Data and Variables}

Estimation of the labor supply model is on data from the most recent wave (2002) of the German Socio-Economic Panel (GSOEP). ${ }^{9}$ The GSOEP is a representative sample of private households living in Germany with detailed information on household incomes, hours worked and household structure. This information is required for both the estimation of the labor supply model and the calculation of hypothetical levels of net household incomes relevant for the simulation of income tax changes. The analysis is restricted to household members who can be expected to vary their labor supply to changes in potential net income. Hence, pensioners, students in full-time education and women on maternity leave are not included in the sample. The self-employed are also excluded because their labor supply behavior can be expected to differ qualitatively. Furthermore, households with missing values in any of the variables entering the calculation of the net household income in alternative hours categories had to be dropped from the sample. Since we use mostly retrospective information on the

8 The assumption that the error terms follow an extreme value distribution is rather restrictive and results in the property of the independence of irrelevant alternatives. Random coefficient models allow for unobserved heterogeneity and therefore circumvent this 'IIA-assumption'. Haan (2004) estimated several labor supply models with the same data set that we use and showed that the results (in terms of labor supply elasticities) from a random coefficients model did not differ significantly from the results from a conditional logit model.

9 A description of the GSOEP can be downloaded from www.diw.de/soep; see also Haisken-DeNew and Frick (2001). 
income variables, the simulations refer to the year 2001. Descriptive statistics on some key variables of our model are given in Table A1 in the appendix.

\section{Hours Categories}

The GSOEP contains information on the number of weekly hours actually worked in the month before the interview, the number of hours „normally“ worked and actually paid overtime hours. The hours variable used here includes paid overtime, i.e. the number of actual hours worked in the reference month. This is the number of normal hours plus paid overtime hours. If a person working overtime hours did not answer the question whether overtime hours are compensated by cash or by shorter working time later on, it was assumed that half of the difference between actual hours worked and average normal hours will be paid (and the other half remunerated by holidays). This part was added to normal average hours.

The definition of the hours categories is motivated by both economic considerations and the actual distribution of hours in the sample. Although a relatively fine aggregation of hours into categories seems desirable in order to realistically approximate the household's budget constraint, the actual distribution of hours in the sample severely restricts the number of possible categories. In particular, men typically do not work part-time and their actual working hours are heavily concentrated between 35 and 40 hours per week. Furthermore, for couples the feasible number of categories is not only restricted by the distribution of hours within one gender, but by the bivariate distribution of the two spouses' working hours. The actual distribution of households in the sample across hours categories is given in Table 1.

Table 1-Distribution of households across hours categories

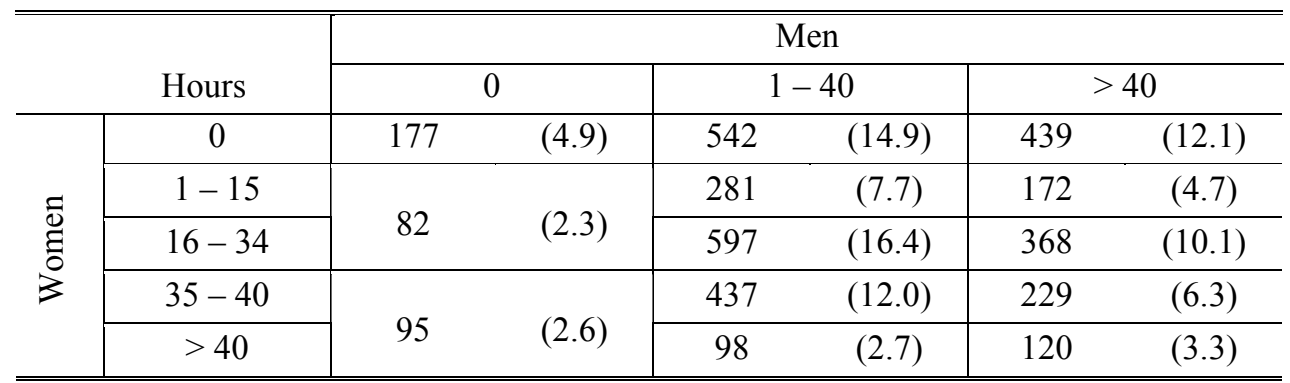

Notes: The first number refers to the absolute frequency in the sample, the second number (in parentheses) to the corresponding relative frequency in percent.

Source: Own calculations, GSOEP, wave 19 (2002).

Because of the small number of men working part-time in our sample, only three categories could be specified for them, namely: non-employment (unemployment and non-participation in the labor force), 1 - 40 hours, and more than 40 hours (overtime). Table 1 shows that about a third (32\%) of all wives in the sample living in couple households do not work, $41 \%$ 
work part-time (defined as working less than 35 hours a week), and 27\% work more than 35 hours a week, i.e. full-time. About $10 \%$ of all husbands in couple households were unemployed in 2001. At the same time, more than a third (37\%) of all husbands worked overtime (more than 40 hours). In about $3 \%$ of all couple households both spouses worked overtime.

The specification of the econometric model is based on the assumption that each household compares the expected utility obtained from net income and the two spouses' leisure associated with the choice of a particular hours category. Here, it is assumed that this comparison is based on the average number of hours worked in a particular category. By subtracting this number from the maximum time budget the household allocates to market work, the average number of hours of leisure corresponding to the choice of a hours category is obtained. For the empirical analysis, the maximum time budget allocated to market work is assumed the same for each household member and is set to 80 hours per week. To test the sensitivity of estimation results with respect to this assumption, the model was also estimated with alternative values for the maximum time budget. Estimation results proved rather insensitive to realistic changes in the value chosen for this parameter. For example, changing the maximum number from 80 to 60 hours per week had very little effect on the estimation results. $^{10}$

\section{Net Household Income}

The derivation of net household income is based on a detailed tax-benefit simulation model which includes all relevant components of the German tax and transfer system. ${ }^{11}$ As regards the calculation of taxable income, earnings from dependent employment, income from capital (interest), property rents, and other income are added to get gross household income. For the great majority of households the most important income component is earnings from dependent employment. For employed people, information on gross monthly earnings in the month before the interview is collected in the GSOEP. This information together with the hours information described above is used to calculate gross hourly wages. Hypothetical monthly earnings for each of the hours categories defined in the previous section are calculated by multiplying gross hourly earnings by the respective average number of working hours in each category. For couples, gross monthly earnings of the household are the sum of the two spouses (hypothetical) earnings in each hours category. For employed persons, it is

\footnotetext{
10 van Soest (1995) reports a similar result in his study for the Netherlands.

11 A description of this tax-benefit simulation model can be obtained from the authors upon request.
} 
assumed that the individual gross hourly wage in their actual hours category would be the same in each hours category. For persons not employed in the month preceding the interview, gross hourly wages are estimated on the basis of empirical wage equations. Due to item nonresponse wages are also missing for a non-negligible share of employed persons, for whom hourly wages are imputed on the basis of these wage equations ${ }^{12}$.

Given (estimated) hourly wages, potential monthly earnings associated with each hours category are calculated for each individual in the sample by simply multiplying the hourly wage with the average number of hours worked per month in each category. Potential gross earnings of each household in each of the 13 hours categories are obtained by simply adding both spouses potential earnings for all categories with positive hours. These estimates of potential monthly earnings are the starting point for the calculation of net household income.

Employees' social security contributions and the income tax are deducted from gross household income and social transfers are added to it to get net household income. Social transfers include child allowances, child-rearing benefits, educational allowances for students and apprentices, unemployment compensation, the housing allowance, and social assistance. Taxable income is calculated by deducting certain expenses from gross household income. The income tax is calculated by applying the income tax formula prevailing in 2001 to taxable income.

Income from self-employment is not taken into account here, because the self-employed and their relatives are not included in the analysis. Information on income from capital and rents is directly taken from the respective questions in the GSOEP. The potential problem of unreliable answers to questions on capital income does not seem too severe in the present context because it would affect estimation results only to the extent that capital income varies with the choice of a particular hours category. However, it may affect the calculation of the hypothecial level of means-tested income support and thereby indirectly also the choice between employment and non-employment in some cases.

\section{Other Variables describing Household Preferences}

For various reasons, household preferences for leisure and income may differ substantially between east and west Germany as well as between natives and foreigners. Preferences may also differ with respect to other individual and household characteristics, such as age, disability and the presence of children in the household. Given their strong work-orientation in the former GDR, east German women may have stronger preferences for work than west

\footnotetext{
${ }^{12}$ Estimation results for these wage equations are available from the authors on request.
} 
German women. On the other hand, compared to married women of foreign nationality, west German women may have a relatively strong work orientation. In general, it seems very likely that households with small children have a stronger preference for "leisure" (nonmarket work) than those without children, and that in couple households the dependence of leisure on the presence of children also varies by gender. Also, it seems likely that preferences for leisure may also depend on age and on disability status.

Due to the relatively small number of households in some of the hours categories, separate estimation of the labor supply models by region and by nationality is not feasible. Structural differences in labor supply behavior between natives and foreigners as well as between east and west Germany are therefore accounted for by interaction terms. These are specified as dummy variables for nationality and region on the one hand, and (the logs of) net household income and the leisure variables on the other. Because of the very small numbers of foreigners living in east Germany, interaction terms for foreigners refer to west Germany only. The leisure variables are also interacted with age and age squared and dummy variables for disability status and, for women, with dummies for the presence of children differentiated by age groups.

On the basis of the data described above the labor supply model specified in the previous section was estimated by the Maximum Likelihood method. Because net household income and leisure time of the two spouses enter the household utility function in linear and quadratic terms as well as interaction terms between each other, the interpretation of single estimated coefficients is not particularly revealing. Therefore, we calculated wage elasticities that can be compared with results from other econometric studies. These elasticities are reported in Appendix 2. ${ }^{13}$

\section{Simulation Results}

Following the discussion in section 2, we simulate two hypothetical alternatives to the current system of household taxation in Germany. Although it is very unlikely to be implemented, we analyze the income and labor supply effects of a shift to individual taxation as a reference case. Secondly, we simulate a shift to the limited real income splitting, which leaves the splitting advantage for married couples in place, but reduces its amount for middle- and high-

13 Detailed estimation results are available from the authors upon request. 
income households. We first present the income effects of the two policy reforms under the assumption of fixed labor supply ${ }^{14}$ and then show the simulated labor supply effects.

\subsection{Income Effects with Constant Labor Supply}

The income change for each household depends on the absolute amount of household income and on the income distribution between the spouses. Therefore, in Table 2 we present the income changes for married couples by the 13 hours categories defined above, by income deciles, and by the number of children.

As expected, income changes are much higher for single-earner couples than for twoearner couples. For spouses with equal labor force participation, the income change gets very small. A shift to individual taxation causes higher differences of the income changes between working hours categories than a shift to limited real income splitting. The modified splitting reform leaves 50 per cent of all married couples (in eastern Germany even 75 per cent) without income change at all. This is a consequence of the possibility to balance income inequalities between spouses up to $40,000 €$ under limited real income splitting.

Income changes by net household income deciles do not follow a clear pattern, because the distribution of incomes between spouses is not taken into account in this depiction. In order to isolate this effect on the income change due to the policy shift, Figure 3 presents the income changes by share of income of the second earner for households with constant pre-tax income. Again, it can be seen that a shift to individual taxation causes much higher income changes than the modified splitting. In households with a pre-tax income between 48,600 and $53,700 €$ per year, only single-earner couples face a decline in net monthly income under limited real income splitting.

Regarding the income changes by number of children in the household, the pattern is as expected: The more children live in the household, the higher the income change under both individual taxation and limited real income splitting. This is due to the fact that with an increasing number of children, the participation rate of women and therefore also the distribution of household income becomes more unequal.

14 A similar analysis based on the 1995 income tax data is contained in Bach and Buslei (2003). 
Table 2-Changes in net household income for married couples resulting from a policy shift to separate taxation or limited real income splitting $(€ /$ month $)$

\begin{tabular}{|c|c|c|c|c|}
\hline & \multicolumn{2}{|c|}{ Individual Taxation } & \multicolumn{2}{|c|}{ Limited Real Income Splitting } \\
\hline & east & west & east & west \\
\hline All (mean) & -76 & -202 & -7 & -33 \\
\hline All (median) & -17 & -154 & 0 & 0 \\
\hline \multicolumn{5}{|c|}{ Mean income changes by hours category ${ }^{\mathrm{a})}$} \\
\hline $0 / 0$ hours $^{\text {a) }}$ & 0 & -14 & 0 & -2 \\
\hline $0 / 22$ & -50 & -43 & -4 & -4 \\
\hline $0 / 40$ & -156 & -218 & -12 & 0 \\
\hline $38 / 0$ & -195 & -339 & -22 & -61 \\
\hline $38 / 9.5$ & -174 & -226 & -32 & -35 \\
\hline $38 / 24$ & -39 & -68 & 0 & 0 \\
\hline $38 / 38$ & -13 & -20 & 0 & 0 \\
\hline $38 / 47$ & -29 & -23 & 0 & 0 \\
\hline $49 / 0$ & -285 & -493 & -41 & -112 \\
\hline 49 / 9.5 & -263 & -347 & -58 & -71 \\
\hline $49 / 24$ & -69 & -154 & 0 & -11 \\
\hline 49 / 38 & -39 & -56 & 0 & 0 \\
\hline $49 / 47$ & -24 & -43 & 0 & -1 \\
\hline \multicolumn{5}{|c|}{ Mean income changes by income deciles ${ }^{\mathrm{b})}$} \\
\hline $1^{\text {st }} \quad(1010)^{b)}$ & -38 & -25 & -1 & -2 \\
\hline $2^{\text {nd }}(1696)$ & -116 & -146 & -16 & -23 \\
\hline $3^{\text {rd }}(2074)$ & -120 & -189 & -16 & -33 \\
\hline $4^{\text {th }}(2391)$ & -57 & -182 & -3 & -24 \\
\hline $5^{\text {th }}(2702)$ & -57 & -176 & -2 & -17 \\
\hline $6^{\text {th }}(3025)$ & -39 & -155 & 0 & -13 \\
\hline $7^{\text {th }}(3375)$ & -46 & -154 & 0 & -11 \\
\hline $8^{\text {th }} \quad(3840)$ & -72 & -218 & 0 & -21 \\
\hline $9^{\text {th }}(4541)$ & -118 & -262 & -16 & -41 \\
\hline $10^{\text {th }}(6463)$ & -165 & -336 & -29 & -101 \\
\hline \multicolumn{5}{|c|}{ Mean income change by number of children ${ }^{\mathrm{c})}$} \\
\hline No children ${ }^{c)}$ & -59 & -147 & -3 & -22 \\
\hline 1 child & -83 & -204 & -9 & -31 \\
\hline 2 children & -73 & -232 & -6 & -39 \\
\hline 3 or more children & -135 & -243 & -14 & -45 \\
\hline
\end{tabular}

Notes: a) Hours categories of two spouses (husband / wife), see table 1, section 3.

b) Income deciles refer to net household income per month; numbers in parentheses refer to the respective decile means for east and west Germany (in $€ /$ month).

c) Number of children under 16 years living in the household.

Source: Own calculations, GSOEP, wave 19 (2002). 
Figure 3-Income changes for married couples with constant pre-tax household income $(48,600-53,700 € /$ year $)$ by income share of second earner

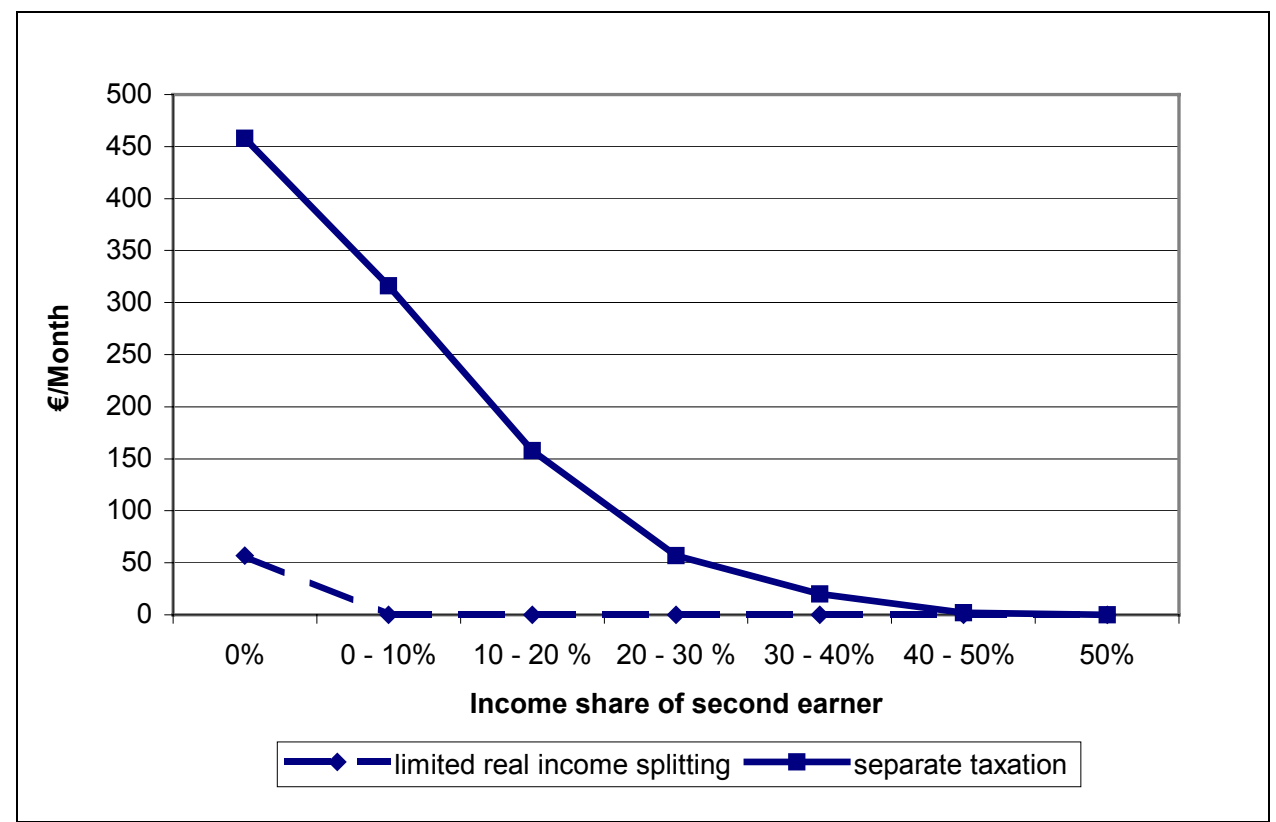

Source: Own calculations, GSOEP, wave 19 (2002).

\subsection{Labor Supply Effects}

The simulated labor supply effects of the two alternative tax reforms are summarized in Table 3. Simulation results refer to changes in both labor force participation rates and changes in total hours. The corresponding labor supply effects in terms of absolute changes in the number of persons are given in Table 4. These numbers were derived by multiplying simulated percentage changes in labor force participation rates by the respective number of households in the GSOEP sample and their respective weighting factor. Below the point estimates we report their respective 95\% bootstrap-confidence bands representing the percentiles of the empirical distribution of the estimated mean of the change in hours and participation rates, respectively. All estimates refer to the sample of married couples on which we have estimated the labor supply model, i.e. these numbers do not include the selfemployed, people younger than 20 or older than 65 years, severely disabled people and women on maternity leave.

Labor supply effects caused by the two policy shifts depend on the income changes by hours categories and the labor supply elasticities of the various groups. Consistent with the pattern of these two factors, the changes in participation and in total hours worked are greater under individual taxation than under limited real income splitting, greater for women than for men and greater in the west than in eastern Germany. 
Table 3-Labor supply effects of a policy shift to separate taxation or limited real income splitting

\begin{tabular}{|c|c|c|c|c|}
\hline & \multicolumn{2}{|c|}{ Individual Taxation } & \multicolumn{2}{|c|}{ Limited Real Income Splitting } \\
\hline & Men & Women & Men & Women \\
\hline \multicolumn{5}{|c|}{ Change in participation rates (in percentage points) } \\
\hline \multirow[t]{2}{*}{ All households } & -0.91 & 4.85 & -0.17 & 1.11 \\
\hline & $(-1.07--0.73)$ & $(4.22-5.66)$ & $(-020--0.15)$ & $(0.95-1.32)$ \\
\hline \multirow[t]{2}{*}{ West, all } & -1.11 & 5.76 & -0.21 & 1.34 \\
\hline & $(-1.31--0.91)$ & $(4.99-6.76)$ & $(-0.24-0.18)$ & $(1.14-1.61)$ \\
\hline \multirow[t]{2}{*}{ West, without children } & -0.66 & 4.71 & -0.20 & 1.21 \\
\hline & $(-0.98-0.32)$ & $(4.04-5.54)$ & $(-0.25--0.16)$ & $(1.03-1.46)$ \\
\hline \multirow[t]{2}{*}{ West, with children } & -1.28 & 6.18 & -0.21 & 1.40 \\
\hline & $(-1.49--1.08)$ & $(5.35-7.30)$ & $(-0.25--0.18)$ & $(1.19-1.69)$ \\
\hline \multirow[t]{2}{*}{ East, all } & -0.14 & 1.32 & -0.03 & 0.20 \\
\hline & $(-0.34-0.12)$ & $(0.87-1.82)$ & $(-0.05-0.00)$ & $(0.13-0.29)$ \\
\hline \multirow[t]{2}{*}{ East, without children } & -0.04 & 0.74 & -0.04 & 0.11 \\
\hline & $(-0.37-0.41)$ & $(0.42-1.09)$ & $(-0.82-0.02)$ & $(0.06-0.19)$ \\
\hline \multirow[t]{2}{*}{ East, with children } & -0.19 & 1.59 & -0.03 & 0.24 \\
\hline & $(-0.37-0.02)$ & $(1.07-2.17)$ & $(-0.06-0.00)$ & $(0.16-0.35)$ \\
\hline \multicolumn{5}{|c|}{ Change in hours (in percent) } \\
\hline \multirow[t]{2}{*}{ All households } & -1.82 & 11.40 & -0.34 & 2.51 \\
\hline & $(-2.11--1.52)$ & $(9.90-13.50)$ & $(-0.40--0.29)$ & $(2.16-3.01)$ \\
\hline \multirow[t]{2}{*}{ West, all } & -2.18 & 13.64 & -0.42 & 3.04 \\
\hline & $(-2.53--1.85)$ & $(11.82-16.27)$ & $(-0.49--0.36)$ & $(2.60-3.68)$ \\
\hline \multirow[t]{2}{*}{ West, without children } & -1.66 & 9.82 & -0.43 & 2.39 \\
\hline & $(-2.18--1.13)$ & $(8.36-11.88)$ & $(-0.53--0.34)$ & $(2.03-2.93)$ \\
\hline \multirow[t]{2}{*}{ West, with children } & -2.38 & 15.16 & -0.41 & 3.30 \\
\hline & $(-2.72--2.05)$ & $(13.10-18.16)$ & $(-0.49--0.35)$ & $(2.81-4.02)$ \\
\hline \multirow[t]{2}{*}{ East, all } & -0.43 & 2.72 & -0.06 & 0.48 \\
\hline & $(-0.72--0.09)$ & $(1.79-3.79)$ & $(-0.10--0.02)$ & $(0.32-0.68)$ \\
\hline \multirow[t]{2}{*}{ East, without children } & -0.40 & 1.54 & -0.09 & 0.30 \\
\hline & $(-0.92-0.21)$ & $(0.89-2.27)$ & $(-0.17--0.01)$ & $(0.17-0.45)$ \\
\hline \multirow[t]{2}{*}{ East, with children } & -0.44 & 3.26 & -0.05 & 0.56 \\
\hline & $(-0.69--0.16)$ & $(2.16-4.54)$ & $(-0.08--0.01)$ & $(0.38-0.80)$ \\
\hline
\end{tabular}

Note: Numbers in parentheses are 95\% bootstrap-confidence intervals based on 1,000 replications and obtained by the percentile method.

In the case of a shift to individual taxation the participation rate of married women increases by about 4.9 percentage points on average, where the estimated $95 \%$ confidence band lies between 4.2 and 5.7. In west Germany, this increase is much higher than in east Germany. This can be explained by the fact that the average income change in the east is only a third of the average income change in the west. The effects on total hours worked follow a similar pattern: the increase in total hours of women in west Germany is more than four times higher than the increase in total hours of women in the east. In total, about 430,000 women would 
join the labor force in case of a shift to individual taxation. A shift to limited real income splitting would result in much weaker labor supply effects than a shift to separate taxation. In total, the female labor force would increase by about 92,000 women in this scenario. The strongest effects can again be found in the group of women in west Germany. Labor supply effects of married men are much smaller than the effects on the labor supply of their spouses. Under both policy alternatives, husbands would reduce their total hours and also their participation rate would decline. This is a result of the incentive to balance the income distribution between the spouses under this tax regime.

Table 4-Labor Supply effects of policy shifts in numbers of thousands

\begin{tabular}{lcc|cc}
\hline \hline & \multicolumn{2}{c|}{ Individual Taxation } & \multicolumn{2}{c}{ Modified Splitting } \\
\cline { 2 - 5 } & Men & Women & Men & Women \\
\hline \multirow{2}{*}{ West } & $-94,435$ & 411,154 & $-17,623$ & 88,903 \\
& $(-115,460--76,058)$ & $(354,760-484,085)$ & $(-21,041-14,448)$ & $(75,855-106,834)$ \\
East & $-2,482$ & 19,658 & -743 & 2,978 \\
& $(-6,146-1,886)$ & $(12,841-27,868)$ & $(-1,195--283)$ & $(1,868-4,474)$ \\
All households & $-96,917$ & 430,812 & $-18,367$ & 91,881 \\
& $(-117,715--76,935)$ & $(374,811-503,731)$ & $(-21,875--15,152)$ & $(78,717-109,725)$ \\
\hline \hline
\end{tabular}

Note: Numbers in parentheses are 95\% bootstrap-confidence intervals based on 1,000 replications and obtained by the percentile method.

\section{Summary and Conclusions}

We have analyzed the potential labor supply effects of a shift from the current system of joint taxation of married couples with income splitting to a system of limited real income splitting, as it has intensively been discussed in the recent election campaign. As a benchmark case, we have also analyzed the potential labor supply effects of a shift to separate taxation, as it is in existence in some other European countries. To this end we have developed a microsimulation model for Germany based on an econometric labor supply model embedded in a detailed empirical tax-benefit model. The labor supply model assumes that married couples jointly maximize a household utility function with both spouses' leisure time and net household income as arguments. This "household-utility" model provides, in our view, a more appropriate specification of actual labor supply behavior of married couples than the alternative specification based on the "male chauvinist" assumption which has been used in previous related studies on the potential labor supply effects of changes in household taxation in Germany. 
We find that a shift from the current system of full income splitting to the hypothetical benchmark of separate taxation of married couples would reduce average net household income substantially in west Germany but only little in east Germany. These regional differences are related to differences in labor force participation and part-time work in the two regions and the fact that the amount of the so-called "splitting advantage" is relatively high for single-earner households of married couples but shrinks quickly with an increasing share of wife's income in total pre-tax household income. The second tax reform we have analyzed in this paper, the limited real income splitting proposal, would on average have very little effect on net household incomes. In fact, this tax reform would leave 50 percent of all married couples (in eastern Germany even 75 per cent) without income change at all. This is a consequence of the possibility to balance income inequalities between spouses of up to 40,000 $€$ under limited real income splitting as analyzed here.

Given these small changes in net household income and the relatively small labor supply elasticities of married women derived from our econometric model, it thus comes as no surprise that our simulation results show relatively small labor supply effects of a shift from the current system of full income splitting to the proposed limited real income splitting system. Overall, we find that female labor supply would increase by about 90 thousand persons, the lion's share of which (almost 90\%) would be in west Germany. For the benchmark scenario of a shift to separate taxation our simulations show that about 430 thousand housewives would be willing to take up work, about 95 percent of them living in west Germany. However, according to our simulation results about 100 thousand husbands would drop out of the labor force following a shift to separate taxation.

The comparison of our simulation results with findings from previous studies for Germany (summarized in section 2.2 above) is rendered difficult by the fact that none of these studies simulates the reform proposal "limited real income splitting" in the way we do. Also the simulations of a shift to individual taxation are not comparable to our simulations, because these authors simulate tax revenue neutral alternatives. Only Wagenhals and Kraus (1998) simulate a policy shift towards separate taxation similar to our case. They get much higher labor supply effects than we do, which is probably due to the authors' model specification, in particular the hypothesis that married couples labor supply model can be described by the "male chauvinist" model.

Overall, our results show that there would be considerable labor supply reactions of married men and women in the case of a shift towards individual taxation in Germany. However, a policy reform of this extent seems rather unlikely at the moment. The more 
realistic alternative, namely a limitation of the current splitting advantage as simulated here, would not lead to major changes in labor supply decisions of married couples.

\section{References}

Althammer, Jörg. 2000. Ökonomische Theorie der Familienpolitik. Heidelberg: PhysicaVerlag.

Bach, Stefan and Hermann Buslei. 2003. Verteilungseffekte des Ehegattensplitting, Mimeo, DIW Berlin.

Blundell, Richard and Thomas MaCurdy. 1999. "Labor Supply: A Review of Alternative Approaches," in Handbook of Labor Economics. Orley Ashenfelter and David Card eds. Amsterdam: Elsevier, pp. 1559-695.

Buslei, Hermann and Viktor Steiner. 1999. Beschäftigungseffekte von Lohnsubventionen im Niedriglohnbereich. Baden-Baden: Nomos.

Dickert-Conlin, Stacy and Scott Houser. 1998. "Taxes and Transfers: A New Look at the Marriage Penalty". National Tax Journal, 51:2, pp. 195-217.

Dingeldey, Irene. 2001. "European Tax Systems and their Impact on Family Employment Patterns." Journal of Social Policy, 30:4, pp. 653-72.

Gustafsson, Siv. 1992. "Separate taxation and married women's labor supply. A comparison of West Germany and Sweden." Journal of Population Economics, 5, pp. 61-85.

Haan, Peter. 2004. Discrete Choice Labor Supply: Conditional Logit vs. Random Coefficient Models. DIW Discussion Paper No. 394: DIW Berlin.

Haisken-DeNew, John P. and Joachim R. Frick. 2001. Desktop Companion to the German Socio-Economic Panel Study (GSOEP): DIW Berlin.

Homburg, Stefan. 2000. "Das einkommensteuerliche Ehegattensplitting." Steuern und Wirtschaft (StuW), 30:3, pp. 261-68.

Killingsworth, Mark R. 1983. Labor Supply. Cambridge: Cambridge University Press.

McFadden, Daniel. 1973. Conditional Logit Analysis of Qualitative Choice Behavior, in Paul Zarembka (ed.), Frontiers in Econometrics, Academic Press.

Spahn, Paul B., Helmut Kaiser, and Thomas Kassella. 1992. "The Tax Dilemma of Married Women in Germany." Fiscal Studies, 13:2, pp. 22-47.

Steiner, Viktor. 2000. "Können durch einkommensbezogene Transfers an Arbeitnehmer die Arbeitsanreize gestärkt werden? Eine ökonometrische Analyse für Deutschland." Mitteilungen aus der Arbeitsmarkt- und Berufsforschung, 33:3, pp. 385-95.

van Soest, Arthur. 1995. "Structural Models of Family Labor Supply: A Discrete Choice Approach." Journal of Human Resources, 30:1, pp. 63-88.

Wagenhals, Gerhard and Margit Kraus. 1998. "Neuansätze des Familienlastenausgleichs," in Frauenpolitische Aspekte im Einkommensteuerrecht, Teil 3. Arbeit und Sozialordnung Hessisches Ministerium für Frauen (ed). Wiesbaden. 
Zimmermann, Klaus F. 1993. Labour Responses to Taxes and Benefits in Germany, 192-240, in: A. B. Atkinson and G. V. Mogensen (eds.): Welfare and Work Incentives. A North European Perspective, Oxford University Press. 


\section{Appendix 1: Descriptive Statistics}

Table A1: Participation rates and average working hours in the sample

\begin{tabular}{|c|c|c|c|c|}
\hline & \multicolumn{2}{|c|}{ east Germany } & \multicolumn{2}{|c|}{ west Germany } \\
\hline & Men & Women & Men & Women \\
\hline \multicolumn{5}{|c|}{ Participation rates in per cent } \\
\hline All married couples & 85 & 76 & 92 & 66 \\
\hline $\begin{array}{l}\text { Married couples } \\
\text { without children }\end{array}$ & 78 & 78 & 87 & 74 \\
\hline $\begin{array}{l}\text { Married couples } \\
\text { with children }\end{array}$ & 89 & 77 & 93 & 63 \\
\hline \multicolumn{5}{|c|}{ Average working hours per week } \\
\hline All married couples & 36 & 27 & 38 & 17 \\
\hline $\begin{array}{l}\text { Married couples } \\
\text { without children }\end{array}$ & 32 & 28 & 36 & 23 \\
\hline $\begin{array}{l}\text { Married couples } \\
\text { with children }\end{array}$ & 37 & 27 & 39 & 14 \\
\hline
\end{tabular}

Source: Own calculations on the basis of GSOEP (wave 19) 2002.

Note: In the sample shown, only married couples are included. Further, all households with head of household or spouse below 20 years or over 65 years are excluded, as well self-employed, students, women on maternity leave and pensioners.

Table A2: Average net household income by hours category (€/month)

\begin{tabular}{lc|c}
\hline $\begin{array}{l}\text { Hours Category } \\
\text { (husband's hours / wife's hours) }\end{array}$ & east Germany & west Germany \\
\hline 0 / 0 & 985 & 1452 \\
0 / 22 & 1464 & 1913 \\
$0 / 40$ & 1763 & 2223 \\
38 / 0 & 1927 & 2771 \\
38 / 9,5 & 2235 & 2863 \\
38 / 24 & 2867 & 3573 \\
38 / 38 & 2992 & 3585 \\
38 / 47 & 3248 & 4448 \\
49 / 0 & 2480 & 3813 \\
49 / 9,5 & 2993 & 3923 \\
49 / 24 & 3192 & 4542 \\
49 / 38 & 3666 & 4605 \\
49 / 47 & 4049 & 5289 \\
\hline \hline
\end{tabular}

Source: Own calculations on the basis of GSOEP (wave 19) 2002.

Note: $\quad$ See note to Table A1. 


\section{Appendix 2: Wage Elasticities of Labor Supply}

The quantitative implications of the labor supply model can best be summarized by hours and participation elasticities with respect to given percentage change in the gross wage rate. These elasticities can be calculated with respect to a change in the own and the spouse's wage. Although a closed-form expression of these wage elasticities is not available for the translog utility function estimated here, they can be calculated from the simulated change in estimated hours and participation rates to an exogenous change in the gross wage rate. At given gross wages, the expected number of hours worked as well as the labor force participation rate can be calculated for each sample observation. Comparing these values to the simulated hours and participation rates resulting from a given percentage change in gross wages yields hours and participation elasticities. In the following table we summarize our elasticity estimates for various population groups.

Overall, estimated own wage elasticities are rather small: measured by hours worked a $1 \%$ wage increase raises labor supply by about $0.3 \%$ for wives and by about $0.2 \%$ for husbands. Estimated elasticities for wives living in west Germany are markedly larger than for east German wives. These regional differences could be related to the greater importance of demand-side restrictions on labor supply as a result of the still very depressed labor market in east Germany. However, it could also be related to a different preference structure of east Germans due to their previous work experience under socialism, or to institutional differences. Similar differences are also observed with respect to participation elasticities. In contrast, cross-wage elasticities between wives and husbands are negligible in both regions and for all household groups considered here. This holds for both hours worked and labor force participation rates.

Comparing labor supply elasticities estimated here with those from previous German studies is rendered difficult by differences in model specification and sample definitions. Overall, estimated elasticities vary greatly between the various studies but all tend to find that (uncompensated) wage elasticities are low for men. For married women, estimated wage elasticities with respect to hours vary between zero and 1.7. Only a few studies also report labor force participation elasticities, and these vary between about 0.8 and 3.3 (for summaries see Zimmermann, 1993, and Steiner, 2000). 
Table A3 - Estimated labor supply elasticities for married spouses (household labor supply model with translog utility function).

\begin{tabular}{|c|c|c|c|c|}
\hline & \multicolumn{2}{|c|}{ Male gross hourly wage $+1 \%$} & \multicolumn{2}{|c|}{ Female gross hourly wage $+1 \%$} \\
\hline & Men & Women & Men & Women \\
\hline \multicolumn{5}{|c|}{ Change in participation rates (in percentage points) } \\
\hline All married couples & $\begin{array}{c}0.15 \\
(0.13-0.17)\end{array}$ & $\begin{array}{c}0.00 \\
(-0.02-0.02)\end{array}$ & $\begin{array}{c}0.02 \\
(0.01-0.03)\end{array}$ & $\begin{array}{c}0.16 \\
(0.14-0.18)\end{array}$ \\
\hline West, all & $\begin{array}{c}0.15 \\
(0.14-0.18)\end{array}$ & $\begin{array}{c}-0.02 \\
(-0.04-0.01)\end{array}$ & $\begin{array}{c}0.01 \\
(0.01-0.02)\end{array}$ & $\begin{array}{c}0.17 \\
(0.15-0.20)\end{array}$ \\
\hline without children & $\begin{array}{c}0.19 \\
(0.16-0.21)\end{array}$ & $\begin{array}{c}-0.02 \\
(-0.04-0.00)\end{array}$ & $\begin{array}{c}0.01 \\
(0.00-0.02)\end{array}$ & $\begin{array}{c}0.17 \\
(0.14-0.19)\end{array}$ \\
\hline with children & $\begin{array}{c}0.14 \\
(0.12-0.16)\end{array}$ & $\begin{array}{c}-0.01 \\
(-0.04-0.01)\end{array}$ & $\begin{array}{c}0.01 \\
(0.01-0.02)\end{array}$ & $\begin{array}{c}0.18 \\
(0.16-0.21)\end{array}$ \\
\hline East, all & $\begin{array}{c}0.13 \\
(0.09-0.17)\end{array}$ & $\begin{array}{c}0.05 \\
(0.03-0.06)\end{array}$ & $\begin{array}{c}0.04 \\
(0.03-0.06)\end{array}$ & $\begin{array}{c}0.10 \\
(0.07-0.13)\end{array}$ \\
\hline without children & $\begin{array}{c}0.18 \\
(0.13-0.23)\end{array}$ & $\begin{array}{c}0.05 \\
(0.03-0.07)\end{array}$ & $\begin{array}{c}0.06 \\
(0.03-0.08)\end{array}$ & $\begin{array}{c}0.09 \\
(0.07-0.12)\end{array}$ \\
\hline with children & $\begin{array}{c}0.10 \\
(0.07-0.14)\end{array}$ & $\begin{array}{c}0.04 \\
(0.03-0.06)\end{array}$ & $\begin{array}{c}0.03 \\
(0.02-0.05)\end{array}$ & $\begin{array}{c}0.10 \\
(0.07-0.12)\end{array}$ \\
\hline \multicolumn{5}{|c|}{ Change in hours (in percent) } \\
\hline All married couples & $\begin{array}{c}0.24 \\
(0.22-0.28)\end{array}$ & $\begin{array}{c}-0.03 \\
(-0.08-0.02)\end{array}$ & $\begin{array}{c}0.02 \\
(0.01-0.03)\end{array}$ & $\begin{array}{c}0.41 \\
(0.36-0.47)\end{array}$ \\
\hline West, all & $\begin{array}{c}0.25 \\
(0.23-0.29)\end{array}$ & $\begin{array}{c}-0.05 \\
(-0.12-0.00)\end{array}$ & $\begin{array}{c}0.01 \\
(0.00-0.02)\end{array}$ & $\begin{array}{c}0.45 \\
(0.40-0.53)\end{array}$ \\
\hline without children & $\begin{array}{c}0.30 \\
(0.26-0.36)\end{array}$ & $\begin{array}{c}-0.08 \\
(-0.13--0.03)\end{array}$ & $\begin{array}{c}0.02 \\
(-0.01-0.03)\end{array}$ & $\begin{array}{c}0.40 \\
(0.35-0.46)\end{array}$ \\
\hline with children & $\begin{array}{c}0.24 \\
(0.21-0.27)\end{array}$ & $\begin{array}{c}-0.04 \\
(-0.11-0.01)\end{array}$ & $\begin{array}{c}0.01 \\
(0.01-0.02)\end{array}$ & $\begin{array}{c}0.48 \\
(0.42-0.55)\end{array}$ \\
\hline East, all & $\begin{array}{c}0.20 \\
(0.14-0.26)\end{array}$ & $\begin{array}{c}0.08 \\
(0.04-0.11)\end{array}$ & $\begin{array}{c}0.06 \\
(0.04-0.08)\end{array}$ & $\begin{array}{c}0.23 \\
(0.17-0.29)\end{array}$ \\
\hline without children & $\begin{array}{c}0.29 \\
(0.21-0.38)\end{array}$ & $\begin{array}{c}0.07 \\
(0.03-0.11)\end{array}$ & $\begin{array}{c}0.09 \\
(0.05-0.13)\end{array}$ & $\begin{array}{c}0.21 \\
(0.16-0.28)\end{array}$ \\
\hline with children & $\begin{array}{c}0.16 \\
(0.11-0.21)\end{array}$ & $\begin{array}{c}0.08 \\
(0.04-0.11)\end{array}$ & $\begin{array}{c}0.05 \\
(0.03-0.07\end{array}$ & $\begin{array}{c}0.24 \\
(0.18-0.30)\end{array}$ \\
\hline
\end{tabular}

Note: Numbers in parentheses are 95\% bootstrap-confidence intervals based on 1,000 replications and obtained by the percentile method. 